\title{
Poultry viscera and bone meal in broiler pre-starter and starter diets
}

\section{Suzany Aparecida Gomes Xavier ${ }^{1^{*}}$, José Henrique Stringhini ${ }^{2}$, Alexandre Barbosa de Brito ${ }^{3}$, Marcos Barcellos Café ${ }^{2}$, Nadja Susana Mogyca Leandro², Maria Auxiliadora Andrade ${ }^{4}$, Michele Laboissière ${ }^{3}$}

\author{
${ }^{1}$ Mestranda do Programa de Pós-Graduação em Ciência Animal (UFG) \\ 2 Departamento de Produção Animal, Escola de Veterinária e Zootecnia (UFG). CNPq fellow. \\ ${ }^{3}$ Doutorando do Programa de Pós-Graduação em Ciência Animal (UFG). \\ ${ }^{4}$ Departamento de Medicina Veterinária, Escola de Veterinária e Zootecnia (UFG).
}

\begin{abstract}
The use of viscera and bone meal in poultry pre-starter and starter diets and its effects on performance, digestive organ development and digestibility and nutrient retention were evaluated. In the first assay, 280-day-old Avian Cobb $^{\circledR}$ chicks were allotted in four experimental groups with five replicates of 14 birds each, in the pre-starter phase; in the second assay, 280 eight-day-old Avian Cobb $48^{\circledR}$ chicks were allotted in four experimental groups with five replicates of 12 birds each. The experimental diet consisted of increasing levels of viscera and bone meal: $0 \%$ (control diet), 3\%, 6\% and 9\% in pre-starter (Assay 1) and starter (Assay 2) diets, to meet nutritional requirements and feed composition proposed by the Brazilian Tables, all of them isonutritive and isoenergetic. A metabolic assay was developed and the total excreta collection was performed from the $4^{\text {th }}$ to the $7^{\text {th }}$ days in Assay 1 and from the $14^{\text {th }}$ to the $17^{\text {th }}$ days in Assay 2 . On these days, one chick per experimental unit, representing the mean body weight of the parcel, was euthanized to perform digestive organ morphometry. Mean body weight was $45.4 \pm 0.4$ on the $1^{\text {st }}$ day in Assay 1 and $179.5 \pm 0.8$ at 8 days of age in Assay 2. In Assay 1 , a negative linear effect was observed for weight gain. Levels of viscera and bone meal influenced quadratically nitrogen digestibility index $\left(\mathrm{Y}=66.0101+0.482425 \mathrm{X}-0.0481086 \mathrm{X}^{2}\right)$ and linearly the digestibility of dry matter $(\mathrm{Y}=71.7775-0.615792 \mathrm{X})$ and ether extract $(\mathrm{Y}=78.3678-0.309136 \mathrm{X})$. Morphometric measures of digestive organs were not influenced by viscera and bone meal levels. For Assay 2, negative and linear effect was observed for viscera and bone meal levels on weight gain $(\mathrm{Y}=551.667-5.08341 \mathrm{X})$ and feed intake $(\mathrm{Y}=955.961-7.48435 \mathrm{X})$. Quadratic effect was observed for ether extract digestibility $\left(\mathrm{Y}=82.557+1.12021 \mathrm{X}-0.150117 \mathrm{X}^{2}\right)$ and maximum point was obtained at $3.7 \%$ viscera and bone meal inclusion for ether extract retention. Mortality was not affected by treatments in either of the assays. Viscera and bone meal can be used at 3 or $4 \%$ inclusion in broiler pre-starter and starter diets.
\end{abstract}

Key Words: animal origin by-products, diets, digestibility, digestive development, performance

\section{Introduction}

Animal-origin byproducts present nutritional and microbiological variations, which result in lack of uniformity of the ingredient and impair broiler performance (Faria Filho et al., 2000). Each animal-origin ingredient must be specifically characterized (Rostagno et al., 2005).

The variation in amino acid content is about $25 \%$ for animal-origin byproducts, while in vegetable byproducts it ranges from 10 to 15\% (Brugalli, 2002). Including animalorigin byproducts in poultry diets can cause an amino acid imbalance, mainly in the non-essential ones (MacLeod, 2001) if their levels are not analyzed. However, these ingredients can result in low feed cost, especially when the ideal protein concept based on digestible amino acids is used (Vieites et al., 2000; Bellaver et al., 2005; Longo et al., 2005).
Animal protein sources significantly reduce nutrient digestibility in chicks from four to seven days of age, especially lipids, because of its effect on pancreas function (Xavier et al., 2004; Xavier et al., 2011). Diets containing broiler viscera meal based on ideal or crude protein concept resulted in better performance for broilers of 43 to 49 days of age (Cancherini et al., 2004). Apparent metabolizable energy values determined for young broilers can be $100 \mathrm{kcal}$ higher than the ones observed for 40-day-old broilers and cockerels (Mello et al., 2009).

Animal feed industries, in many cases, obtain the nutritional composition of feedstuffs, but this is done only after feed production and animal consumption. Because of that, a systematic control of the quality of ingredients is recommended, in order to make it possible to obtain preliminary results and decide about their inclusion or not in animal diets (Brugalli, 2002). 
The objective of this experiment was to evaluate broiler performance with pre-starter and starter diets formulated with different levels of viscera and bone meal inclusion and the effects on nutrient digestibility and digestive organ measures.

\section{Material and Methods}

Two assays were carried out in order to evaluate performance and nutrient digestibility of broilers in two periods. A total of 280 chicks in the pre-starter phase (1 to 7 days of age) and 240 chicks in starter phase (8 to 21 days of age), both from Avian Cobb $48^{\circledR}$ genetic strain, was used. Chicks were standardized according to the starter weight and divided into four groups with five replicates with 14 and 12 chicks each, half of each sex, in the pre-starter and starter phases of the experiment, respectively.

In both assays, broilers received the experimental diets, corresponding to the different inclusion levels of viscera and bone meal. The viscera and bone meal used contained 93.9\% dry matter, $10.2 \%$ nitrogen and $11.3 \%$ ether extract, and was obtained by frying in high temperature (110 to $120^{\circ} \mathrm{C}$ ) in conventional fixed volume digesters; after, the fat was extracted by compression.

Four brood batteries of galvanized steel, with five floors and $0.80 \times 0.75 \times 0.25 \mathrm{~m}$ (length $\times$ width $\times$ height) pens in a mansory shed were used. The batteries warming was performed by $60 \mathrm{~W}$ incandescent lamps exposing broilers to 12 hours of natural light and 12 hours of artificial light per day. The batteries were equipped with linear feeders and drinkers, cleaned and supplied twice a day. Warming was controlled daily and associated to the curtains handling to maintain the temperature in the hall adequate to broilers.

Experimental diets were formulated taking into account the levels of viscera and bone meal inclusion, as follows: $0 \%$ (Control diet), 3\%, 6\% and 9\% in pre-starter (Table 1 ) and starter (Table 2) diets. Diets were formulated to meet the nutritional recommendations and feedstuffs composition proposed by Rostagno et al. (2005); all of them were isonutritive and isoenergetic.

Live weight and feed intake were determined weekly; the number and weight of dead birds were registered and used to calculate the mortality index and corrected feed intake and feed conversion. The following variables were analyzed: weight gain, feed intake, feed conversion and mortality rate (transformed into arcsine $(\% / 100)^{0.5}$ to statistical analysis).

From the $4^{\text {th }}$ to the $7^{\text {th }}$ day (pre-starter phase experiment) and from the $14^{\text {th }}$ to the $17^{\text {th }}$ days of age (starter phase experiment), a digestibility assay was conducted. Total excreta collection method was used, and excreta were collected twice a day. At the end, the excreta collected were prepared in a pool of the daily samples, homogenized and maintained in freezer for analysis. Bromatological analyses of diets and excreta were performed in the Laboratório de Nutrição Animal of the Escola de Medicina Veterinária e Zootecnia of the Universidade Federal de Goiás (EVZ/UFG). Dry matter (DM), crude protein (CP) and ether extract (EE) were determined according to the methodology proposed by Silva \& Queiroz (2002). Results were used to determine the digestibility coefficient (DC\%) of diets, following the formula proposed by Matterson et al. (1965): DC (\%) = ((Nutrient in diets\% - Nutrient in excreta\%) / Nutrient of $\operatorname{diet} \%) \times 100$

Table 1 - Calculated composition of the experimental diets (pre-starter phase assay)

\begin{tabular}{|c|c|c|c|c|}
\hline \multirow[b]{2}{*}{ Ingredients } & \multirow[b]{2}{*}{ Control diet } & \multicolumn{3}{|c|}{$\begin{array}{c}\text { Viscera and bone } \\
\text { meal content }\end{array}$} \\
\hline & & $3 \%$ & $6 \%$ & $9 \%$ \\
\hline Corn grain & 55.82 & 56.96 & 58.10 & 59.23 \\
\hline Soybean meal & 36.78 & 32.06 & 27.34 & 22.62 \\
\hline Wheat meal & 1.00 & 2.54 & 4.08 & 5.62 \\
\hline Dicalcium phosphate & 1.85 & 1.45 & 1.05 & 0.65 \\
\hline Limestone & 1.02 & 0.97 & 0.93 & 0.88 \\
\hline Soybean oil & 2.25 & 1.66 & 1.08 & 0.50 \\
\hline Viscera and bone meal & 0.00 & 3.00 & 6.00 & 9.00 \\
\hline Common salt & 0.47 & 0.35 & 0.23 & 0.10 \\
\hline $\begin{array}{l}\text { Mineral and vitamin } \\
\text { supplement* }\end{array}$ & 0.40 & 0.40 & 0.40 & 0.40 \\
\hline Sodium bicarbonate & 0.00 & 0.13 & 0.27 & 0.40 \\
\hline DL-methionine & 0.24 & 0.24 & 0.24 & 0.24 \\
\hline L-lysine $\mathrm{HCl}$ & 0.17 & 0.21 & 0.25 & 0.30 \\
\hline L-threonine & 0.00 & 0.01 & 0.02 & 0.03 \\
\hline L-tryptophan & 0.00 & 0.01 & 0.02 & 0.03 \\
\hline \multicolumn{5}{|c|}{ Calculated nutritional composition } \\
\hline Crude protein, \% & 22.00 & 22.00 & 22.00 & 22.00 \\
\hline AMEn, kcal/kg & 2950 & 2950 & 2950 & 2950 \\
\hline Calcium, \% & 0.99 & 0.99 & 0.99 & 0.99 \\
\hline Available phosphorus, \% & 0.46 & 0.46 & 0.46 & 0.46 \\
\hline Potassium, \% & 0.85 & 0.80 & 0.74 & 0.69 \\
\hline Sodium, \% & 0.23 & 0.23 & 0.23 & 0.23 \\
\hline Digestible lysine, \% & 1.18 & 1.18 & 1.18 & 1.18 \\
\hline Digestible met+cys, \% & 0.83 & 0.83 & 0.83 & 0.83 \\
\hline Threonine, \% & 0.74 & 0.74 & 0.74 & 0.74 \\
\hline Digestible tryptophan, \% & 0.25 & 0.25 & 0.25 & 0.25 \\
\hline Chlorine, \% & 0.36 & 0.31 & 0.26 & 0.21 \\
\hline Mongin, $\mathrm{mEq} / \mathrm{kg}$ & 216 & 216 & 216 & 216 \\
\hline
\end{tabular}

* Micromineral and vitamin supplement for broiler starter phase, minimum levels per kilogram of product: vitamin A - 3,125,000 IU; vitamin D3 - 550,000 IU; vitamin E - 3,750 mg; vitamin K3 - 625 mg; vitamin B1 - 250 mg; vitamin B2 1,125 mg; vitamin B6 - 250 mg; vitamin B12 - 3,750 mcg; niacin - 9,500 mg; calcium pathotenate - 3,750 mg; folic acid - $125 \mathrm{mg}$; DL-methionine - 350,000 mg; $50 \%$ choline chloride - 150,000 mg; growth promoter - $12,500 \mathrm{mg}$; anticoccidial agent - 15,000 mg; selenium - $50 \mathrm{mg}$; antioxidant - 2,500 mg; vehicle q.s. - 1,000 g. AMEn - apparent metabolizable energy corrected by nitrogen; met+cys methionine + cystine. 
Table 2 - Calculated composition of the experimental diets (starter phase assay)

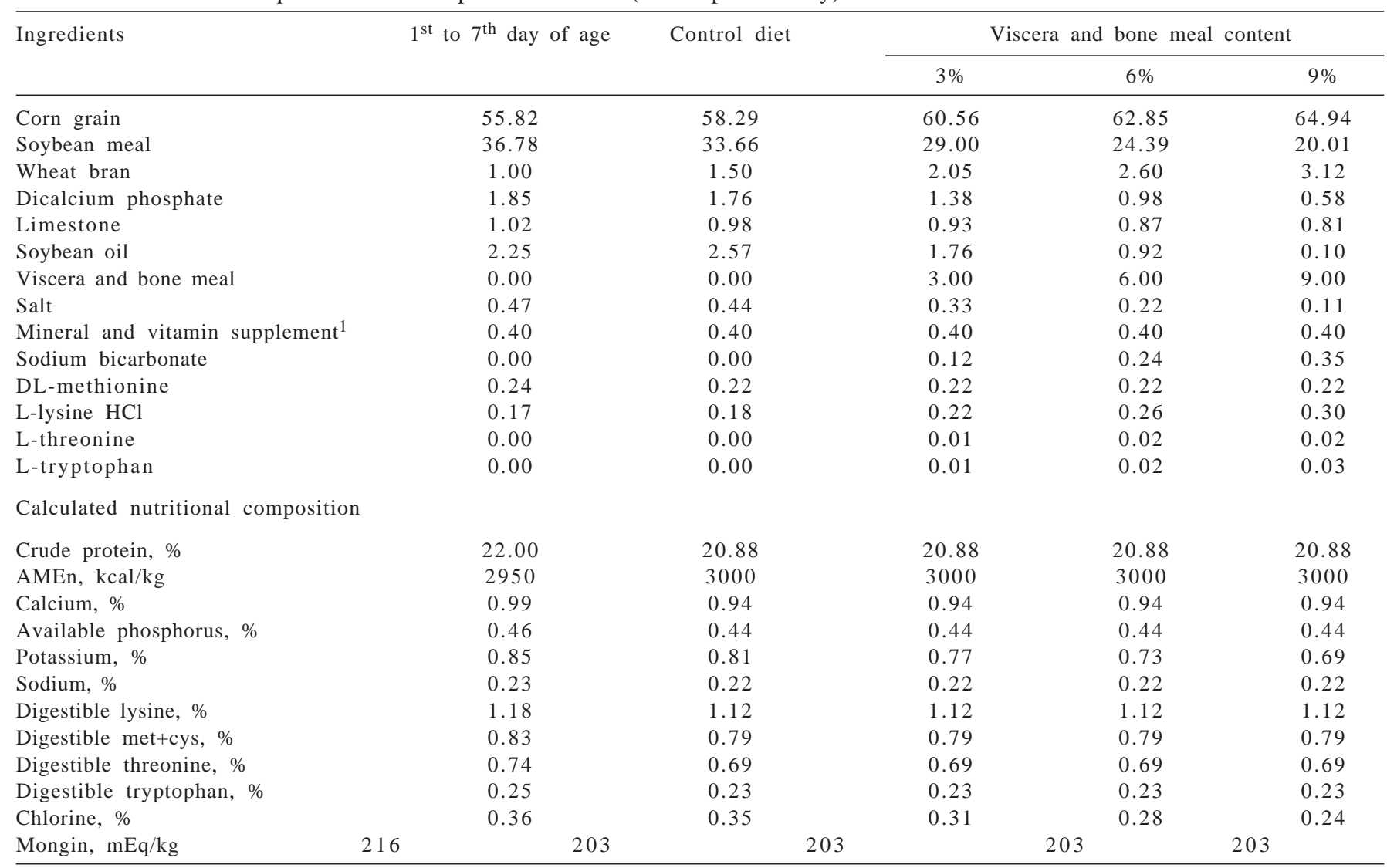

${ }^{1}$ Micromineral and vitamin supplement for broiler starter phase, minimum levels per kilogram of product: vitamin A - 3,125,000 IU; vitamin D3 - 550,000 IU; vitamin E - 3,750 mg; vitamin K3 - 625 mg; vitamin B1 - 250 mg; vitamin B2 - 1,125 mg; vitamin B6 - 250 mg; vitamin B12 - 3,750 mcg; niacin - 9,500 mg; calcium pathotenate - 3,750 mg; folic acid - $125 \mathrm{mg}$; DL-methionine - 350,000 mg; 50\% choline chloride - 150,000 mg; growth promoter - 12,500 mg; anticoccidial agent - 15,000 mg; selenium - $50 \mathrm{mg}$; antioxidant - 2,500 mg; vehicle q.s. - 1,000 g.

AMEn - apparent metabolizable energy corrected by nitrogen; met+cys - methionine + cystine.

Nutrient retention was calculated as a ratio between the nutrient balance and the weight gain registered from the fourth to the seventh day of age (pre-starter phase) and from the $17^{\text {th }}$ to the $21^{\text {st }}$ day of age (starter phase), according to Noy \& Sklan (2002).

From the fourth to the seventh days of age (pre-starter phase assay) and from the $14^{\text {th }}$ to the $17^{\text {th }}$ days of age (starter phase assay), one chick per replicate was selected, weighed, transported to the Laboratório de Doenças das Aves of the Departamento de Medicina Veterinária and euthanized by cervical dislocation to determine the biometrical indexes related to the bird weight, as follows: esophagus + crop; proventriculus + gizzard; small intestine; pancreas, liver + gall bladder; and small and large intestines length. The values, except for intestines length, were expressed in percentage of live weight.

The statistical analysis was performed by ANOVA in a completely randomized design, with four treatments and five replicates each, using the software SAEG (Sistema para Análises Estatísticas, version 7.1), by employing the polynomial regression until third degree.

\section{Results and Discussion}

The mean values of temperature (minimum 25.1 and maximum $30.8{ }^{\circ} \mathrm{C}$ ) and air humidity (minimum 41.3 and maximum 56.8\%) observed during the experiments were considered normal for the geographic region in which the experiments were carried out and did not interferewith the experimental results. The average bird weight in prestarter assay was $45.4 \pm 0.4$ (average weight on the 1st day of age) and of $179.5 \pm 0.8 \mathrm{~g}$ (average weight on the 8th day of age) in the starter phase assay.

In the pre-starter assay, viscera and bone meal did not affect ( $\mathrm{P}>0.05$ ) broiler performance (Table 3$)$. In the total period ( 1 to 21 days of age), negative linear effect $(\mathrm{P}<0.05)$ was observed for weight gain $(\mathrm{Y}=691.606-4.23968 \mathrm{X})$. This data indicated that the use of high levels of viscera and bone meal determined a significant reduction in the performance variables at older ages.

Unlike the results observed in this experiment, Bellaver et al. (2001) observed that diets with 5\% of viscera and bone meal in substitution of soybean meal resulted in better 
broiler performance in the growing phase, but diets with 3\% of viscera and bone meal did not affect performance until 21 days of age (Bellaver et al., 2005). Laboissiere (2008) verified that the best performance in the pre-starter phase was achieved with $9.0 \%$ of viscera and bone meal obtained from different processing systems (varying cooking temperature and moisture). The inclusion of this ingredient resulted in $7 \%$ (Bellaver et al., 2001) to 14\% (Girotto et al., 2002) cost reductions compared with soybean meal.

By evaluating the digestibility data from the pre-starter assay (Table 4), one can observe that the levels of viscera and bone meal linearly increased $(\mathrm{P}<0.05)$ the digestibility coefficient of dry matter $(\mathrm{Y}=71.816+0.487182 \mathrm{X})$ and ether extract ( $\mathrm{Y}=78.3325-0.8120488 \mathrm{X})$. Quadratic effect $(\mathrm{P}<0.05)$ was observed for nitrogen digestibility coefficient $\left(\mathrm{Y}=66.0108+0.48242 \mathrm{X}-0.048108 \mathrm{X}^{2}\right)$, and the maximum point of the quadratic curve was obtained with $5 \%$ viscera and bone meal inclusion in the diet. For nutrient retention data obtained from the pre-starter phase assay (Table 4), it is possible to observe that the viscera and bone meal levels reduced retention coefficients of nitrogen $(\mathrm{Y}=32.784$ $0.079964 X)$ and ether extract $(Y=49.0154-1.2668 X)$ linearly
$(\mathrm{P}<0.05)$. This significant reduction in nitrogen and fat retention due to the levels of viscera and bone meal may corroborate the reduction observed in performance variables.

The inclusion of viscera and bone meal in pre-starter diets $(\mathrm{P}>0.05)$ had no effect on morphometric measures (Table 5). Bellaver et al. (2005) and Laboissiere (2008) did not find difference in broiler organs with viscera and bone meal in diets either.

In the starter phase assay, performance was affected (Table 6) by viscera and bone meal inclusion and a negative linear effect was observed for weight gain $(\mathrm{Y}=551.667$ 5.08341X) and feed intake ( $\mathrm{Y}=955.961-7.48435 \mathrm{X})$. Therefore, high levels of viscera and bone meal in the broiler starter phase may reduce performance. However, it is important to emphasize that the use of viscera and bone meal depends on their nutritional and sanitary quality and processing system (Nascimento et al., 2002; Penz Júnior et al., 2005, Laboissière, 2008). Nevertheless, Laboissière (2008) verified that pre-starter diets with $9.0 \%$ of viscera and bone meal increased broiler performance, but she emphasized that adequate processing reflects the nutritional and sanitary quality of this ingredient.

Table 3 - Performance of broilers fed increasing levels of viscera and bone meal in pre-starter diets

\begin{tabular}{|c|c|c|c|c|c|c|c|c|c|c|}
\hline & \multicolumn{3}{|c|}{1 to 7 days of age } & \multicolumn{3}{|c|}{8 to 21 days of age } & \multicolumn{3}{|c|}{1 to 21 days of age } \\
\hline & & WG, g & FI, g & FC & WG, g & FI, g & FC & WG, g & FI, g & FC \\
\hline \multirow{4}{*}{$\begin{array}{l}\text { Viscera and bone } \\
\text { meal levels }\end{array}$} & $0 \%$ & 130.6 & 153.6 & 1.176 & 568.4 & 891.9 & 1.569 & 686.4 & 1021.5 & 1.488 \\
\hline & $3 \%$ & 133.3 & 152.8 & 1.147 & 562.2 & 880.4 & 1.566 & 683.4 & 1009.5 & 1.477 \\
\hline & $6 \%$ & 131.3 & 153.6 & 1.171 & 573.1 & 901.2 & 1.572 & 689.7 & 1026.5 & 1.488 \\
\hline & $9 \%$ & 133.2 & 152.7 & 1.146 & 535.1 & 852.6 & 1.594 & 656.1 & 980.0 & 1.494 \\
\hline CV, \% & 3,01 & 2.87 & 2.18 & 4.27 & 4.97 & 1.70 & 3.76 & 4.42 & 1.67 & \\
\hline $\mathrm{R}^{2}$ & - & - & - & - & - & - & 0.60 & - & - & \\
\hline Effect & ns & ns & ns & $\mathrm{ns}$ & ns & ns & L & ns & ns & \\
\hline Probability & $>0.5$ & $>0.5$ & 0.16 & 0.09 & 0.36 & 0.37 & 0.02 & 0.38 & $>0.5$ & \\
\hline
\end{tabular}

WG - weight gain; FI - feed intake; FC - feed conversion; ns - non-significant effect ( $\mathrm{P}>0.05)$; CV - coefficient of variation; $\mathrm{L}$ - linear effect for viscera and bone meal inclusion levels.

Table 4 - Data of metabolic assay obtained from 4 to 7 days of age with chicks fed increasing levels of viscera and bone meal in pre-starter diets

\begin{tabular}{|c|c|c|c|c|c|c|c|}
\hline & & \multicolumn{3}{|c|}{ Digestibility coefficent (\%) } & \multicolumn{3}{|c|}{ Retention coefficient (mg/g) } \\
\hline & & EE & $\mathrm{N}$ & $\mathrm{EE}$ & $\mathrm{DM}$ & $\mathrm{N}$ & $\mathrm{EE}$ \\
\hline \multirow[t]{4}{*}{ Viscera and bone meal levels } & $0 \%$ & 71.6 & 65.4 & 81.2 & 914.4 & 32.0 & 49.5 \\
\hline & $3 \%$ & 73.7 & 68.8 & 79.9 & 921.7 & 34.2 & 47.5 \\
\hline & $6 \%$ & 73.8 & 65.4 & 79.8 & 926.8 & 31.2 & 45.5 \\
\hline & $9 \%$ & 74.6 & 64.0 & 78.1 & 923.2 & 32.3 & 48.7 \\
\hline $\mathrm{CV}, \%$ & 0,8 & 2.7 & 1.5 & 2.9 & 2.8 & 3.2 & \\
\hline $\mathrm{R}^{2}$ & 0,84 & 0.71 & 0.93 & - & 0.82 & 0.75 & \\
\hline Effect & $\mathrm{L}$ & $\mathrm{Q}$ & $\mathrm{L}$ & ns & L & L & \\
\hline Probability & 0.001 & 0.029 & 0.001 & $>0.500$ & 0.001 & 0.001 & \\
\hline
\end{tabular}

EE - ether extract; N - nitrogen; DM - dry matter; ns - non-significant effect (P>0.05); L - linear or Q - quadratic effect for viscera and bone meal inclusion levels; $\mathrm{CV}$ - coefficient of variation. 
Haqui et al. (1991) verified that $9.3 \%$ of viscera meal in diets, extruded or not, did not affect broiler performance. Escalona \& Pesti (1987) included 0, 5 and $10 \%$ of poultry byproducts in broiler diets and observed that $10 \%$ inclusion affected performance with reduced weight gain and worsened feed conversion.

The digestibility assay carried out during the starter phase experiment (Table 7), showed that viscera and bone meal inclusion in diets affected $(\mathrm{P}<0.05)$ ether extract digestibility coefficient $(\mathrm{Y}=82.557+1.12021 \mathrm{X}-$ $\left.0.150117 \mathrm{X}^{2}\right)$ and ether extract retention coefficient $(\mathrm{Y}=$ $\left.\mathrm{Y}=63.6312+4.64598 \mathrm{X}-0.665865 \mathrm{X}^{2}\right)$. The maximum points obtained with these quadratic equations were $3.7 \%$ and $3.5 \%$ of viscera and bone meal inclusion in diets, respectively, for ether extract digestibility and retention coefficients. Wang \& Parsons (1998) verified that temperature and time of processing also reduced amino acid digestibility, which could affect protein digestion and metabolism in broilers, although it did not occur in this experiment.
Morphometric measures of digestive organs were not affected by the levels of viscera and bone meal included in broiler starter diets (Table 8). Contraryly to the results observed in this experiment, Longo et al. (2003) obtained differences in liver weight, small intestine length and weight using protein sources in pre-starter diets (soybean isolated protein, powdered egg, blood plasma, corn gluten $60 \%$ and dried yeast). Brito et al. (2004) compared different animal byproduct-based diets with vegetable-based diets and did not observe any difference in digestive organ relative weights.

Analyzing all the results obtained in these two experiments, it can be observed that high levels of viscera and bone meal gradually reduced performance in broilers. Diets based on the ideal protein concept, as proposed by Baker \& Han (1994), are more efficient when alternative ingredients to corn and soybean meal are included, and animal byproducts are considered good alternatives. However, it is important to stress that processing methods must guarantee nutritional and sanitary quality (Wang \& Parsons, 1998; Laboissière, 2008).

Table 5 - Digestive organ dimensions of broilers fed increasing levels of viscera and bone meal in pre-starter diets

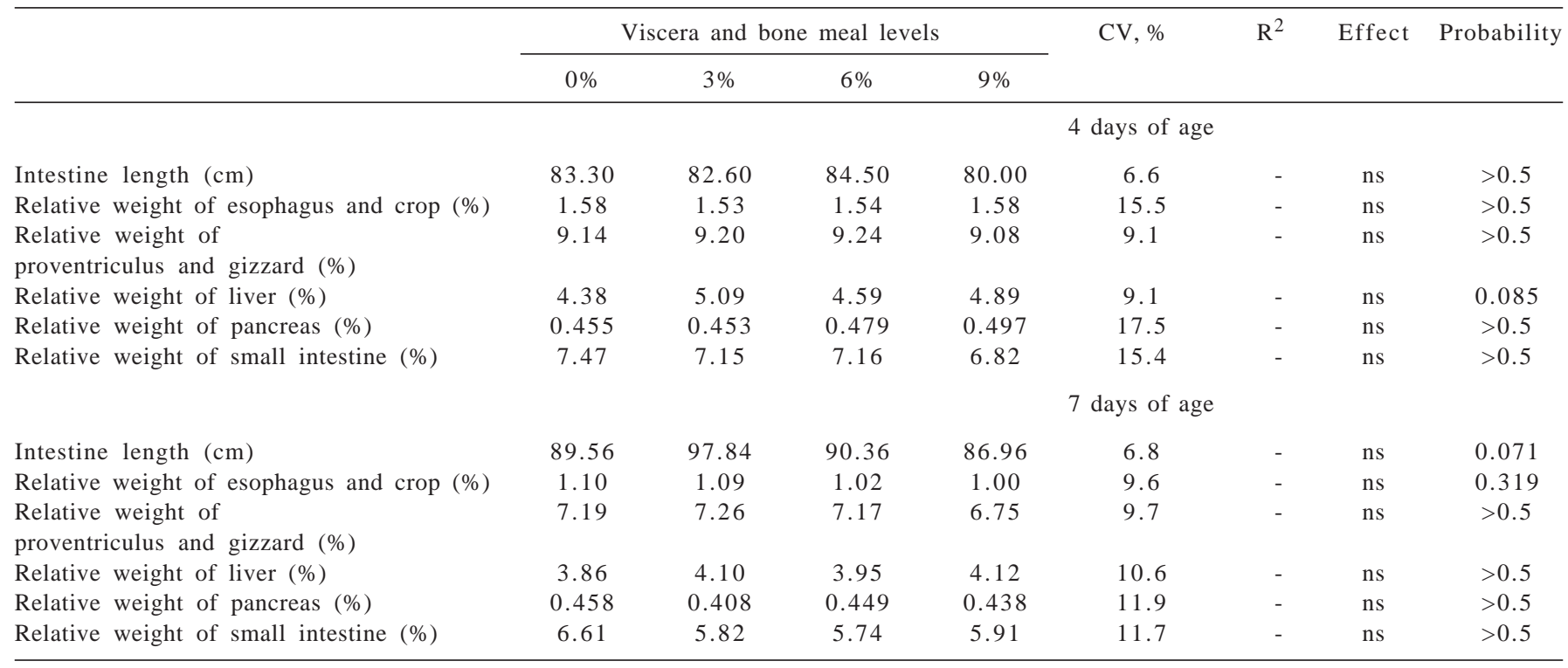

ns - non-significant effect $(\mathrm{P}>0.05)$; CV - coefficient of variation.

Table 6 - Performance of broilers fed increasing levels of viscera and bone meal in starter diets

\begin{tabular}{lcccc}
\hline & & Weight gain, g & Feed intake, g & Feed conversion, g \\
\hline Viscera and bone meal levels & $0 \%$ & 546.1 & 954.5 & 929.5 \\
& $3 \%$ & 541.1 & 953.4 & 1.748 \\
& $6 \%$ & 548.9 & 896.6 & 1.718 \\
& $9 \%$ & 509.6 & 2.70 & 1.762 \\
\hline Coefficient of variation, \% & 4.68 & 4.42 & - & $\mathrm{ns}$ \\
$\mathrm{R}^{2}$ & 0.63 & 0.61 & $>0.5$ \\
Effect & $\mathrm{L}$ & $\mathrm{L}$ & & \\
Probability & 0.05 & 0.03 & & \\
\hline
\end{tabular}

ns - non-significant effect $(\mathrm{P}>0.05)$; L - linear effect for viscera and bone meal inclusion levels. 
Some aspects may help to explain such reductions. According to Bellaver et al. (2001), the inclusion of 5\% viscera meal in broiler diets increased performance when diets were formulated based on the ideal protein concept. The authors suggested that the amount of digestible isoleucine in diets became insufficient when viscera meal in the diet was over 5\%. El-Sheikh et al. (1996) indicated that the supplementation of methionine and lysine to broiler diets containing viscera meal increased nitrogen use and performance.

Alleman et al. (2000) offered a plausible explanation for the reduced performance. These authors affirmed that animal protein sources have a complex tertiary structure compared with the vegetable ones. Therefore, the limited enzymatic secretion and the complexity of the protein structure can explain the reduction in nitrogen and fat retention when higher levels of viscera and bone meal were used, hence the reduced performance and digestibility indexes.
The inclusion of animal byproducts in diets resulted in higher dry matter digestibility which, possibly, can be justified by the increased inclusion of corn. The digestibility of carbohydrates is relatively simpler than protein. Likewise, the inclusion of animal byproducts reduced digestion and absorption of fats, which can be justified by the lower inclusion of soybean oil in diets. Besides, on the first posthatch days, chicks are not completely mature to digest and absorb nutrients, especially fat (Chambers \& Gray, 1979; Moran Jr., 1994; Krogdahl \& Sell, 1989).

Despite these problems, the use of such animal byproducts can be viable in moderate levels considering their nutritional and sanitary quality. According to Penz Júnior et al. (2005), the most visible loss when animal byprodutcs and fats are not included in broiler diets is the increase of production costs. In a practical view, animalorigin ingredients and fats can be replaced by vegetable oils, soybean meal and dicalcium phosphate; however, for

Table 7 - Data of metabolic assay obtained from 17 to 21-day-old chicks fed increasing levels of viscera and bone meal in starter diets

\begin{tabular}{|c|c|c|c|c|c|c|c|}
\hline & & & ty coe & & Ret & coeffic & \\
\hline & & DM & $\mathrm{N}$ & $\mathrm{EE}$ & DM & $\mathrm{N}$ & $\mathrm{EE}$ \\
\hline Viscera and bone meal levels & $0 \%$ & 74.2 & 64.6 & 82.5 & 1267.6 & 42.4 & 63.8 \\
\hline & $3 \%$ & 76.0 & 67.6 & 84.9 & 1342.5 & 46.8 & 71.0 \\
\hline & $6 \%$ & 76.3 & 65.8 & 83.6 & 1414.3 & 45.1 & 68.1 \\
\hline & $9 \%$ & 74.3 & 62.4 & 80.6 & 1261.1 & 39.8 & 51.3 \\
\hline $\mathrm{CV}, \%$ & 3.9 & 7.0 & 3.9 & 11.8 & 13.5 & 10.8 & \\
\hline $\mathrm{R}^{2}$ & - & - & 0.98 & - & - & 0.99 & \\
\hline Effect & ns & ns & $\mathrm{Q}$ & ns & ns & $\mathrm{Q}$ & \\
\hline Probability & $>0.5$ & 0.36 & 0.03 & 0.39 & 0.29 & 0.001 & \\
\hline
\end{tabular}

EE - ether extract; N - Nitrogen; DM - dry matter; ns - non-significant effect (P>0.05); L - linear or Q - quadratic effect for viscera and bone meal inclusion levels; $\mathrm{CV}$ - coefficient of variation.

Table 8 - Digestive organ dimensions of broilers fed increasing levels of viscera and bone meal in starter diets

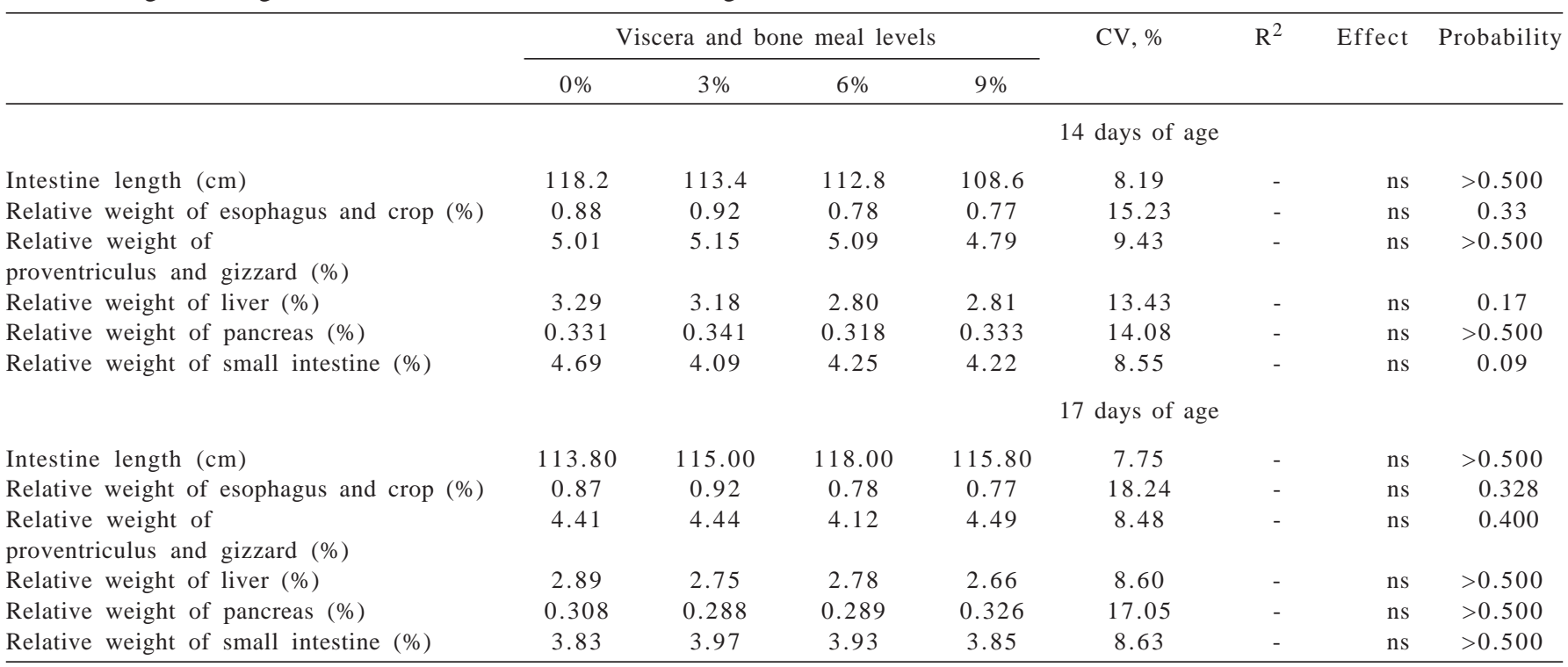

ns - non-significant effect ( $\mathrm{P}>0.05)$; CV - coefficient of variation. 
the same protein level, higher inclusion levels of synthetic amino acids are required, which increase production costs (Bellaver et al., 2005).

\section{Conclusions}

Viscera and bone meal can be recommended at the inclusion level of 3 and $4 \%$ in pre-starter and starter diets for broilers, respectively.

\section{References}

ALLEMAN, F.; MICHEL, J.; CHANGNEU, A.M. et al. The effects of dietary protein independent of essential amino acids on growth and body compositions in genetically lean and fat chickens. British Poultry Science, v.41, p.214-218, 2000.

BAKER, D.H.; HAN, Y. Ideal amino acid profile for chicks during the first three weeks posthatching. Poultry Science, v.73, p.1441-1447, 1994.

BELLAVER, C.; BRUM, P.A.R.; LIMA, G.M.M. et al. Substituição parcial do farelo de soja pela farinha de vísceras de aves em dietas balanceadas com base na proteína e em aminoácidos totais ou digestíveis para frangos de corte. Revista Brasileira de Ciência Avícola, v.3, n.3, p.233-240, 2001.

BELLAVER, C.; COSTA, C.A.F.; AVILA, V.S. et al. Substituição de farinhas de origem animal por ingredientes de origem vegetal em dietas para frangos de corte. Ciência Rural, v.35, n.3, p.671-677, 2005.

BRUGALLI, I. Variação de aminoácidos nos ingredientes importância prática e aplicação do NIRS para controlar a variabilidade. In: SIMPÓSIO SOBRE INGREDIENTES NA ALIMENTAÇÃO ANIMAL, 2002, Uberlândia. Anais... Campinas: CBNA, 2002. v.2, p.277-284.

CANCHERINI, L.C.; JUNQUEIRA, O.M.; ANDREOTTI, M.O. et al. Utilização de subprotudos de origem animal em dietas para frangos de corte com base em proteínas bruta e ideal, no período de 43 a 49 dias de idade. Revista Brasileira de Zootecnia, v.33, n.6, p.2060-2065, 2004 (supl.2).

CHAMBERS, C.; GRAY, R.D. Development of the structural components of the brush border in absorptive cells of the chick intestine. Cell Tissue Research, v.204, p.387-405, 1979.

EL-SHEIKH, M.A.M.; SOLIMAN, A.F.; ABDELLA, M.M. et al. The nutritive value of hydrolyzed feather and poultry offal meals in broiler rations. Annals of Agricultural Science, v.34, p.157-170, 1996

FARIA FILHO, D.E.; JUNQUEIRA, O.M.; FARIA, D.E. et al. Avaliação dos tipos de farinha de carne e ossos sobre o desempenho de frangos de corte machos. Revista Brasileira de Ciência Avícola, v.2, supl.2, p.19, 2000.

GIROTTO, A.F. Como amenizar a crise da suinocultura. Revista Porkworld, v.2, n.9, p.20-23, 2002.

HAQUI, A.K.M.A.; LYONS, J.J.; VANDEPOPULIERE, J.M. Extrusion processing of broiler starter diets containing ground whole heans, poultry byproduct meal, feather meal, or ground feathers. Poultry Science, v.70 p.234-240, 1991.

KROGDAHL, A.; SELL, J. Influence of age on lípase, amylase and protease activities on pancreatic tissue and intestinal contents of young turkeys. Poultry Science, v.68, p.1561-1568, 1989.
LABOISSSIERE, M. Valor nutricional de farinhas de penas e sangue e de vísceras e ossos para frangos de corte. 2008. 70f. Dissertação (Mestrado em Ciência Animal) - Universidade Federal de Goiás, Goiânia.

LONGO, F.A.; MENTEM, J.F.M.; PEDROSO, A.A. et al. Diferentes fontes de proteína na dieta pré-inicial de frangos de corte. Revista Brasileira de Zootecnia, v.34, n.1, p.112-122, 2005.

LONGO, F.A.; MENTEN, J.F.M.; PEDROSO, A.A. et al. Diferentes fontes de proteína na dieta pré-inicial de frangos de corte. Revista Brasileira de Zootecnia, v.34, n.1, p.112-122, 2005.

MacLEOD, M.G. Efeito do balanço entre aminoácidos e a relação energia/proteína sobre o seu metabolismo: desempenho e composição corporal em frangos de corte. In: SIMPÓSIO INTERNACIONAL ACAV DE NUTRIÇÃO DE AVES, 2. 2001, Concórdia. Anais... Concórdia: EMBRAPA, 2001. p.64-81.

MATTERSON, L.D.; POTTER, L.M.; STUTZ, M.W. et al. The metabolizable energy of feeds ingredients for chickens Connecticut: University of Connecticut Press, 1965. 11p.

MELLO, H.H.C., GOMES, P.C., ROSTAGNO, H.S. et al. Valores de energia metabolizável de alguns alimentos obtidos com aves de diferentes idades. Revista Brasileira de Zootecnia, v.38, n.5, p.863-868, 2009.

MORAN JR., E.T. Digestão e absorção de gorduras. In: FACTA. Fisiologia da digestão e absorção das aves. Campinas: FACTA, 1994. p.71-82.

NASCIMENTO, A.H.; GOMES, P.C.; ALBINO, L.F.T. et al. Composição química e valores de energia metabolizável das farinhas de penas e de vísceras determinados por diferentes metodologias para aves. Revista Brasileira de Zootecnia, v.31, n.3, p.1409-1417, 2002 (supl.).

PENZ JÚNIOR, A.M.; DARI, R.L.; SHIROMA, N. Consequências das dietas formuladas sem proteínas de origem animal. In: CONFERÊNCIA APINCO DE CIÊNCIA E TECNOLOGIA AVÍCOLAS, 2005, Santos. Anais... Campinas: FACTA, 2005. p.249-256.

ROSTAGNO, H.S.; ALBINO, L.F.T.; DONZELE, J.L. et al. Tabelas brasileiras para aves e suínos. Viçosa, MG: UFV - Imprensa Universitária, 2005. 186p.

ROSTAGNO, H.S.; ALBINO, L.F.T.; DONZELE, J.L. et al. Tabelas brasileiras para aves e suínos. Viçosa, MG: UFV - Imprensa Universitária, 2000. 61p.

SILVA, D.J.; QUEIROZ, A.C. Análise de alimentos: métodos químicos e biológicos, 3.ed. Viçosa, MG: Editora UFV, 2002. $235 p$.

VIEITES, F.M.; ALBINO, L.F.T.; SOARES, P.R. et al. Valores de energia metabolizável aparente da farinha de carne e ossos para as aves. Revista Brasileira de Zootecnia, v.29, n.6, p.2262-2299, 2000.

WANG, X.; PARSONS, C.M. Dietary formulation with meat and bone meal on total versus digestible or bioavailable amino acid basis. Poultry Science, v.77, p.1010-1015, 1998.

XAVIER, S.A.G.; STRINGHINI, J.H.; BRITO, A.B. et al. Digestibilidade e retenção de nutrientes de frangos de corte consumindo dietas com diferentes fontes protéicas na fase pré-inicial. Revista Brasileira de Ciência Avícola, supl.6, p.83, 2004.

XAVIER, S.A.G.; STRINGHINI, J.H.; BRITO, A.B. et al. Feather and blood meal in pre-starter and starter diets for broilers. Revista Brasileira de Zootecnia, v.40, n.8, p.1745-1752, 2011. 